\title{
Traktörlerde Kullanılan Teknolift Mandalının Ergonomik Olarak Geliştirilmesi
}

\section{Ergonomic Development of Tractor Technolift Clamp}

\author{
Yasin Ulu $\bullet$, Mehmet İskender Özsoy*®
}

Sakarya Üniversitesi Mühendislik Fakültesi Makine Mühendisliği Bölümü, Sakarya, TÜRKIYE

Sorumlu Yazar / Corresponding Author*: iozsoy@sakarya.edu.tr (*)

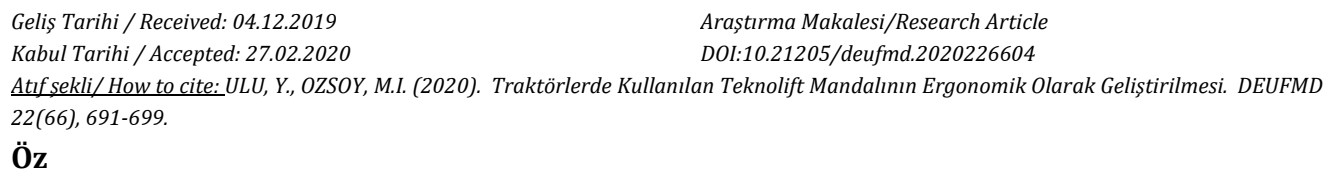

$\mathrm{Bu}$ çalışmada traktörlerde kullanılan mevcut teknolift mandal mekanizmalarına ergonomiklik kazandırılması ve mekanizmaya uygulanan yükün azaltılması amacıyla ve ergonomik açıdan tutma biçimleri göz önüne alınarak yeni bir teknolift mandal mekanizması tasarlanmıştır. Yapılan bu tasarım hızlı prototipleme yöntemi ile üretilerek traktör üzerindeki ergonomikliği kontrol edilmiştir. Diğer taraftan araç üzerine monte edilen yeni mekanizmanın üzerine gelen yükler dijital kuvvet ölçer ile ölçülerek teorik hesaplama sonucuyla karşılaştırılmıștır. Ölçümler neticesinde deneysel ve teorik sonuçların birbirine yakın olduğu görülmüştür. Diğer taraftan elde edilen yük değerleri bu yeni tasarımın yaklaşık \%58-72 oranında daha az bir yükleme ile çalışacağını göstermektedir. Bu durum traktör başındaki kullanıcının daha az kuvvet harcayacağını göstermektedir. Bununla birlikte geliştirilen alternatif kol tasarımının kol/omuz desteğiyle ittirileceği için uzun süreli kullanımlarda herhangi bir fiziksel sorun teșkil etmeyeceği ve iș verimliliğine olumlu yönde katkı yapacağını düşünülmektedir.

Anahtar Kelimeler: Traktör, teknolift, hidrolik kaldırıcl, ergonomi

\section{Abstract}

In this study, a new technolift lever mechanism has been designed as an alternative in order to provide ergonomics to the existing technolift clamp mechanisms used in tractors and to reduce the load applied to the mechanism. In this context, a new technolift latch mechanism has been designed considering the ergonomically holding types. This design is produced by rapid prototyping method and ergonomic design is controlled on the tractor. On the other hand, the loads on the new mechanism mounted on the vehicle were measured with the load cell and compared with the theoretical calculation result. As a result of the measurements, it was seen that experimental and theoretical results were close to each other. On the other hand, the load values indicate that this new design will operate with a 58-72\% less load. This shows that the user at the head of the tractor will consume less force. However, since the developed alternative arm design will be pushed with arm / shoulder support, it is considered that it will not cause any physical problems in long-term use and will contribute to the productivity positively.

Keywords: Tractor, technolift, hydraulic lift, ergonomics 


\section{Giriş}

Tarımda kullanılan mekanik araçlar, iş ve kuvvet makinelerinden olușmaktadır. Traktörler, kuvvet makineleri olarak tarımda kullanılan önemli araçlar arasında bulunmaktadır ve günümüzde traktörler teknolojinin gelişimiyle birlikte tek bir amaç yerine birçok farklı amaç için kullanılmaya bașlanmıștır [1].

Hidrolik kaldırıcılar, traktör ile traktörün arkasına takılan ekipmanlar arasındaki bağlantıyı sağlayan aktarım organlarıdır [2]. Hidrolik kaldırıcılar traktörlerde; taşıma, indirme, kaldırma, otomatik derinlik kontrolü, yüzer pozisyon ve pozisyon kontrol fonksiyonlarını yerine getirmektedirler. Şekil 1a ve Şekil 1b' de bir hidrolik kaldırıcının iki boyutlu resmi ve diferansiyel sistemi üzerine montajlanan resmi verilmiştir. Buna göre hidrolik kaldırıcı kolları, hidrolik kaldırıcı sistemi üzerinde bulunan ve ekipmanların, traktörlerin arkasına bağlantısını sağlayarak istenilen yükseklik seviyesinde tutan elemanlardır. $\mathrm{Bu}$ yükseklik seviyesi pozisyon kontrol elemanı ile gerçekleşmektedir. Aynı zamanda traktörün çalıșması esnasında yol/arazi şartlarına bağlı olarak bu yükseklik seviyesinin hassasiyetinin korunması derinlik kontrol elemanı ile sağlanmaktadır. Teknolift levye ise ayarlanan bu pozisyon ve derinlik kontrollerine göre hidrolik kaldırıcı kollarını devreye alıp devreden çıkaran elemandır [3].

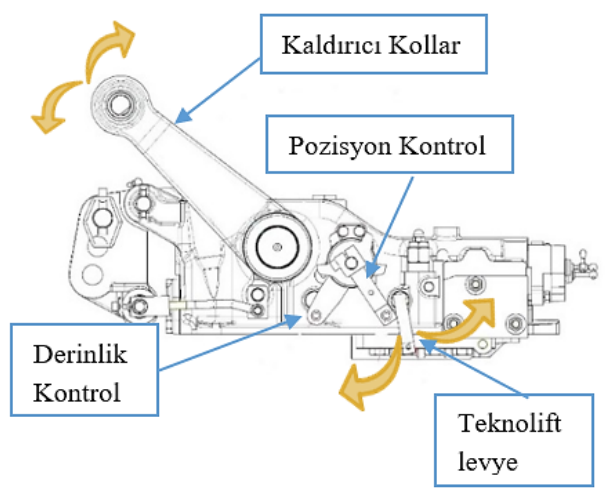

Şekil 1a. Hidrolik kaldırıcı [3]

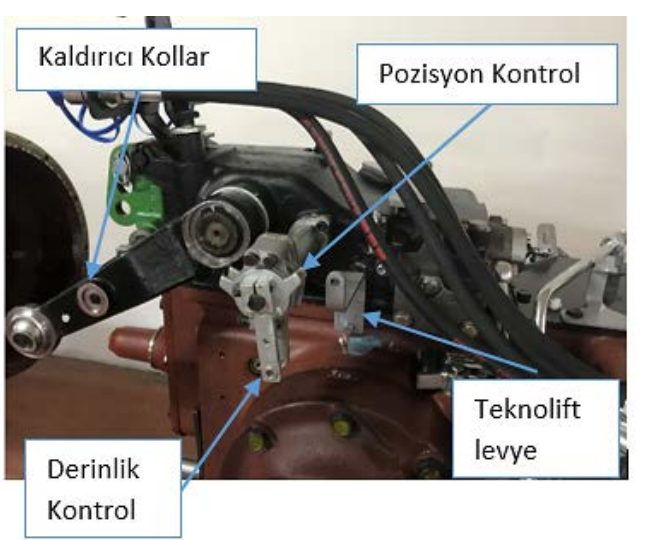

Şekil 1b. Hidrolik kaldırıcının diferansiyel üzerine montajlı hali [3]

Herry Ferguson, 1921-1933 ylları arasında hidrolik kaldırma sistemlerinin geliştirilmesi ile ilgili ilk çalışmaları yapmıştır [4]. İlk defa 1933 yılında seri olarak üretilmeye başlanan hidrolik kaldırıcılı traktörler o günün koșullarında hidrolik el pompası yani kas gücüyle çalıștırılırken, günümüz modern traktörlerinde ise hidrolik pompalar ile çalıştırılmaktadır.

Bununla birlikte bu aparatlar ile çalışan kullanıcıların kumanda kolları ile uyumlarının istenen verimliliğin sağlanması açısından kullanıcı/alet ara yüzünün en uygun düzeyde olması gerekmektedir. Bu yüzden ergonomi bilimine ihtiyaç duyulmaktadır.

Ergonomi, çalışanın iş ortamı ile olan ilişkilerini araştırarak, iş ortamının ve işinin insanın kabiliyetlerine ve özelliklerine uygunluğunu sağlar. İnsanın performansını yükseltmek için oluşabilecek sakatlıkları azaltma amacı vardır. Çalışanın iş ortamı ve çalışma biçiminde yapılacak her iyileștirme sağlığını, rahatını ve iş güvenliğini arttıracağından performansını da yükseltecektir [5-7].

İncelenen çalıșmaların bir kısmında Hindistan, İran ve Nijerya gibi ülkelerin arazi yapılarını ve kullanıcıların antropometrik yapılarını da göz önüne alarak ergonomi çalıșmaları yapılmaktadır. Bu kapsamda Mehta ve diğerleri [8], Hindistan'daki traktör kullanıcılarının pedallara uyguladıkları kuvveti incelemișlerdir. $\mathrm{Bu}$ çalışma kapsamında bir ölçüm düzeneği kurularak kullanıcının pedalların konumuna bağlı olarak sağ ve sol ayağı tarafından pedallara uygulanan kuvvetler bulunmuş ve bu değerlere göre pedalların konumlarını belirlemişlerdir. 
Feyzi ve diğerleri [9], bir deneysel düzenek tasarlayarak operatör tarafından kontrolkumanda aletleri üzerine uygulanan kuvvetleri ölçmüşlerdir. Bunun için İranlı sürücülere yönelik ayak basma kuvvetleri, el çekme ve basma kuvvetleri ve her iki el tarafindan uygulanan tork değerlerini incelemișlerdir. Buna göre el ve ayak için, direksiyon, vites kolu ve pedallara uygulanması gereken en yüksek kuvvet değerlerini belirlemişlerdir. Yisa [10], iki tür traktör markasını Nijeryalı kullanıcılar için ergonomik açıdan incelemişlerdir. Bununla ilgili olarak kullanıcıların pedal ve kontrol organlarına erişimleri, koltuk tasarımı, direksiyon muhafazası, çalışma alanı ve kumandalar ile iklimsel ve çevresel șartlara uygunluk açısından incelemișlerdir. Ayrıca operatörlerin sürüş esnasındaki duruşları da incelenen çalışmalar arasında yer almaktadır. Daeijavad ve Maleki [11], sonlu elemanlar tekniğini kullanarak uygun duruş için traktör koltuğu açllarını incelemișlerdir ayrıca yapılan simülasyon çalışmalarının doğruluğunu laboratuvar testleri ile doğrulamıșlardır. Mehta ve Tewari [12], traktör sürücü koltuklarının ergonomik olarak tasarımına yardımcı olmak amacıyla traktör bel operatörünün bel omurları üzerindeki yükleri tahmin etmek için bir biyomekanik model geliștirmișlerdir. $\mathrm{Bu}$ modelin amacı farklı çalışma koşullarında omurlar üzerine gelen basma ve kesme yüklerini tahmin etmektir. Bunun için operatörlerin boy ve ağırlığını, çalışma koşullarını ve reaksiyon kuvvetlerini dikkate alarak model kurmușlardır ve belirlenen kuvvetler sonucunda sürücü koltuğu tasarımını gerçekleştireceklerdir. Li ve diğerleri [13], traktör sürücülerinin doğru sürüş duruşunu deneysel ve istatiksel yöntemler kullanarak belirlemișlerdir. Bu kapsamda ön ve arka duruş konumlarını etkileyen sürücülerin bel çevresi, bacak uzunluğu, oturma yüksekliği ve kabin düzeni gibi parametreler incelenmiş ve ölçümler üç eksendeki koordinatları ölçen bir makine ile elde edilmiș ve lineer regresyon metodu ile bir tahmin modeli kurulmuștur. Sonuçlara bakıldığında sürücülerin sürüș duruşları için deneysel sonuçların ve tahmin edilen değerlerin birbirleri ile uyumlu olduğunu belirtmișlerdir.

Çalışma esnasındaki titreșimin sürücüye vereceği rahatsızlıkları belirlemek amacıyla sahada deneysel çalışmalar yapılmaktadır. Mehta ve diğerleri [14], traktör ekipmanlarından kaynaklanan sürüş titreşimlerini ölçerek en uygun çalıșma süresini belirlemișlerdir. Ölçüm sonuçlarına göre kullanıcının traktör sürme zamanının pulluklama ve tırmıklama sürme işleminin 2,5 saati aşmaması gerektiğini ve bu sürenin aşılması durumunda rahatsızlıklar, ağrı ve yaralanmalara maruz kalınabileceğini belirtmișlerdir. Dewangan ve Tewari [15], el traktörleri kullanan sürücülerin yorgunluğunu azaltmak için farklı çalışma koşullarında maruz kalınan titreşimleri ölçerek hız değerlerine göre titreşim ivmelerini elde etmişlerdir.

Yapılan ergonomi çalışmaları yalnızca operatörlerin araç sürüşü esnasında sınırlı kalmayıp aynı zamanda yardımcı ekipmanlar, ulaşım araçlarının yönlendirilmesi, parçaların tasarımı ve kurulumu gibi süreçlerde de yer almaktadır. Lin ve Xu [16], kamyon römorklarının mekanik olarak çevirme koluyla indirilip kaldırılması ile ilgili bir çalıșma yapmışlardır. On iki katılımcı ile laboratuvar ortamında yaptıkları çalışmada çevirme koluyla yapılan işlemin skapular hareket açıklığı ve omuz kası aktivitesi üzerine etkileri gözlenmiștir. Yapılan çalışmalar sonucunda römorku indirirken ve kaldırırken kol ve omuz sağlığı açısından duruş pozisyonlarını belirtmişlerdir. Rajan ve diğerleri [17] havacıllk endüstrisine yönelik montaj ürünleri ve jig tasarımları operasyonlarında çalışma esnasındaki duruş analizi için ergonomi çalışması yapmışlardır. Bu kapsamda modeller sanal gerçeklik tabanlı bir ortama aktarılarak bir izleme sisteminde incelenir. $\mathrm{Bu}$ izleme sisteminde kullanıcının hareketleri yakalanır ve montaj esnasında kullanıcının erişilebilirlik ve ergonomi analizi yapılır. Muffet ve diğerleri [18], demiryolu sinyal kutularında kullanılan kaldıraç kollarına uygulanan itme ve çekme kuvvetleri nedeniyle oluşan ve duruştan kaynaklananan yaralanmaların önüne geçmek ve personel güvenliğini arttırmak için bir çalıșma yapmışlardır. Çalışma kaldıraç ağırlıklarının ölçümüne ve bunun bilgisayar destekli biyomekanik modelleme tahminleriyle karşılaştırılmasına dayanır. Yapılan çalışmada kol ağırlıkları, özel olarak tasarlanmış bir cihaz kullanılarak ölçülmüştür. Veriler çekme kuvvetleri ve çalışma duruşları göz önüne alınarak bilgisayar yazllımına girilerek analiz edilmiştir. Analiz sonuçlarında çekme ve itme durumları için gereken ükler belirlenmiştir

Diğer taraftan iş makinesi gibi araçlarda arayüz tabanlı ve kabin içindeki düğme, kumanda ve 
pedallara erișimi kolaylaștırmak amacıyla geliștirmeler yapılmaktadır. Akyeampong ve diğerleri [19], bir hidrolik ekskavatörün ergonomisini geliştirmek amacıyla daha kullanışlı bir insan-makine arayüzü tasarlamışlardır. Bu amaçla koordinat kontrollü baș üstü ekranlı ve kumanda kolu kontrollü baș üstü ekranlı arayüz geliştirmişlerdir. Nathanael ve Marmaras [20], vatmanların kabin içindeki çalışma alanlarını daha fonksiyonel olacak şekilde yeniden tasarlamışlardır. Bu kapsamda daha sağlıklı sürüș için oturma destek sistemleri ve diğer yönden konsol ve kumanda kollarını yeniden tasarlamışlardır.

Traktör kullanıcılarına yönelik yapılan diğer bir çalışmada ise Kuta ve diğerleri [21], dinamik yükler karşısında traktör sürücülerinin el pozisyonu için en uygun çalışma aralığını incelemișlerdir. Bu kapsamda maksimum kas kasılması ve kol ve bileğe gelebilecek en düşük yük ve dirsek açısı belirlenerek direksiyon muhafazasının konumunu ayarlamışlardır.

Şekil 2'de Mary Marzke'nin objeleri tutma sınıflandırması görülmektedir. Buna göre birinci tutma şekli parmak uçlarıyla kavrama, ikinci tutma șekli avuç içinde sıkıștırarak tutma ve üçüncü tutma şekli de parmaklar açık olacak şekilde el pençesiyle kavramadır. [22;23].
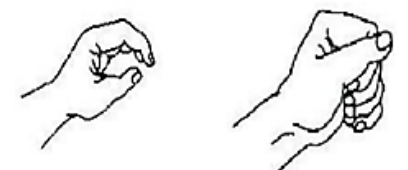

Avuç içi kavrama

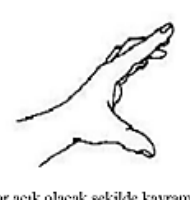

Şekil 2. Mary Marzke'nin temel kavrama çeşitleri [24;23]

$\mathrm{Bu}$ çalışmada literatürdeki mevcut tasarımlara göre hidrolik kaldırıcı kollarını harekete geçiren teknolift mandalları incelendiğinde, kullanım kolaylığını (ergonomisini) arttırmak için tarım aracını kullanan operatörün parmakla kullanımı yerine yaklaşık olarak \% 50 daha az kuvvet harcayarak el-kol ile kullanımı hedeflenmiștir. Teknolift mandalı, tasarım kriterlerine uygun olarak PRO/Engineer adlı 3 boyutlu katı modelleme programında modellenmiștir. Yapılan tasarım hızlı prototipleme yöntemi ile üretilerek traktör üzerine takılıp denenmiştir. Traktör üzerinde takılı olan teknolift mandalı üzerine gelen yükler yük hücresi ile ölçülerek karşılaştırılmıştır.

\section{Mataryel ve Metot}

\subsection{Teknolift levyeyin çalıșma yükü}

Hidrolik kaldırıcı üzerindeki teknolift levyeye gelen yükü bulmak için önce mandal üzerine gelen yük hesaplanmıștır. Bunun için Șekil 3'te gösterildiği gibi bir dijital kuvvet ölçer kullanılarak teknolift mandal üzerine gelen yük farklı traktörler üzerinde ölçülmüştür. Bu ölçümlerde görülen değerler en yüksek $12.5 \mathrm{~kg}$ ve en düșük 8.2 kg'dır. Sekil 4-6'da teknolift mandal mekanizmaları gösterilmiştir.

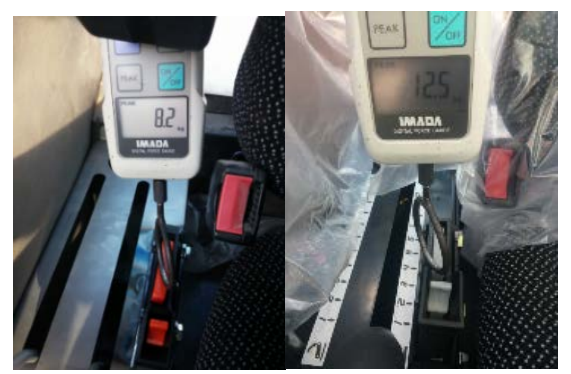

Şekil 3. Mevcut teknolift mandallarının yük ölçümleri

Parmakla bastırılan nokta üzerinden kaldıraç denklemi kullanılarak (Denklem 1), D noktasındaki gerekli stroğu yani mekanizmanın çalışabilmesi için gerekli olan minumum mesafeyi sağlayacak yükler hesaplanmıștır. ( Şekil 4).

$\frac{F_{1} \times X_{1}}{X_{2}}=F_{2}$

Burada $F_{1}$ kuvveti, $X_{1}$ kuvvetin dönme eksenine uzaklığını, $X_{2}$ yükün dönme eksenine uzaklığını $F_{2}$ yükü ifade etmektedir.

Denklem (1)'deki kaldıraç formülüne göre yapılan hesaplamalar sonucunda, teknolift levyesinin tasarımı gereği $10 \mathrm{~mm}$ 'lik çalışma mesafesini tamamlayabilmesi için 29,500 dönmesi gerekmektedir ve bunun gerçekleșmesi için teknolift levyeye (D noktası) $19 \mathrm{~kg}$ ile $30 \mathrm{~kg}$ arasında yük uygulanması gerekmektedir ( Şekil $5)$.

Şekil 5'teki değerlere göre hidrolik kaldırıcı kollarının tarlaya uygun hassasiyet ve yükseklik değerleri ayarlanması ile birlikte kullanıcının bu ayarları değiștirmeden devam edebilmelidir. Bu nedenle hidrolik kaldırıcı kollarının aynı seviyeye indirilip kaldırılmasına yarayan teknolift mandalının kullanımı literatürde bulunan tasarımlarda fazla güç gerektirmekte ve kullanım zorluğu olușturmaktadır. 
Traktörlerde kullanılan mevcut teknolift mandallarnın çalıșması için bașparmak ile bastırılması gerekmektedr. Bu işlem sonucunda mekanizmanın çalışma mesafesine ulaşabilmesi için yaklaşık $19 \mathrm{~kg}$ ile $30 \mathrm{~kg}$ arası yük uygulanması gerekmektedir.

$\mathrm{Bu}$ hareketi, telli veya mekanik mevcut sistemler ile yapmak için parmakla mevcut mandala yaklaşık $\quad 8 \quad \mathrm{~kg}$ ile $12.5 \quad \mathrm{~kg}$ arasında yük uygulanması gerekmektedir. Tarla sürümünde her tarlanın başına/sonuna gelindiğinde traktör operatörünün teknolift mandalını çok sık aralıklarla kullanımından dolayı yorgunluk hissi vereceği düşünülmektedir. Bununla birlikte Gregor ve Bojan [25], bir el aletini kullanırken kullanım süresinin uzun süre devam etmesi durumunda, kötü tasarlanmış bir alet tutamağı, el ve kolun rahatsızlık hissine ve kümülatif travma bozukluklarına neden olabileceğini belirtmişlerdir.
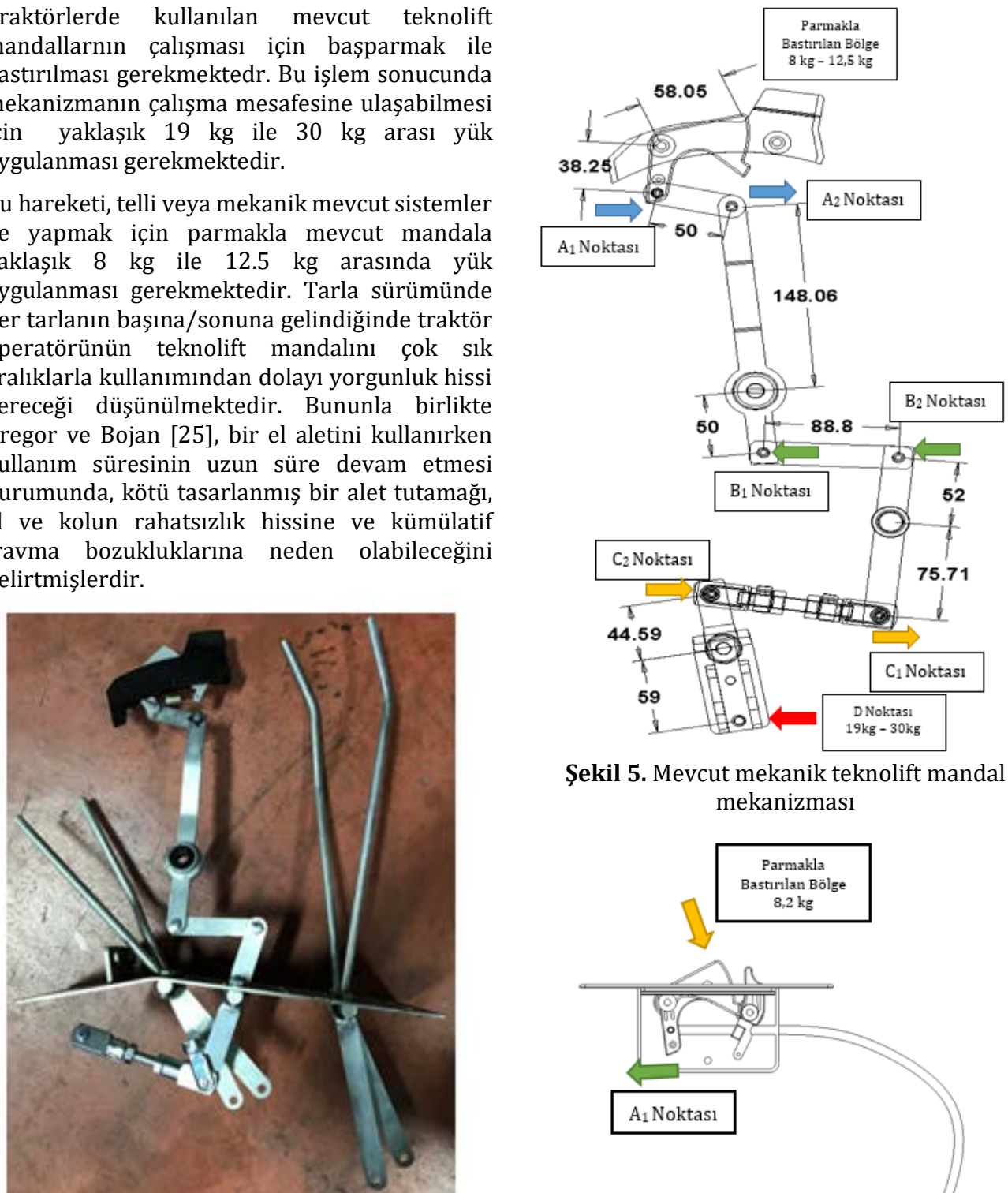

Sekil 5. Mevcut mekanik teknolift mandal mekanizması

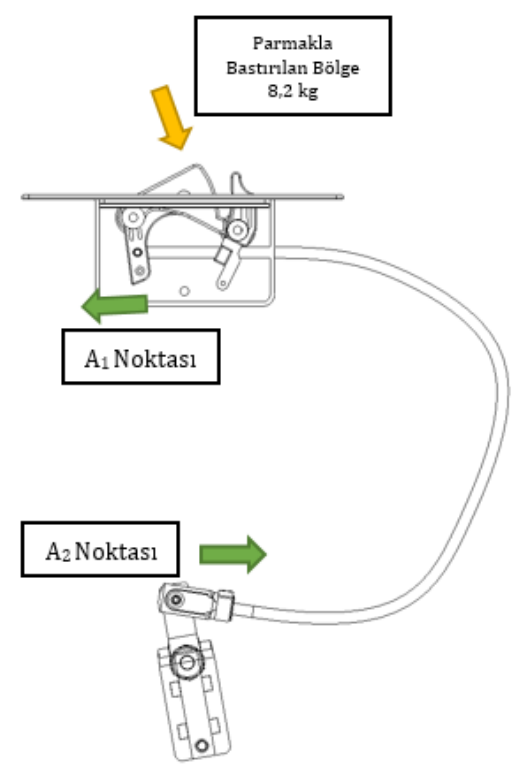

Sekil 6. Mevcut telli teknolift mandal mekanizması 


\subsection{Geliştirilen Alternatif Model}

Şekil 7'de mevcut model verilmiştir. Alternatif model tasarımındaki öncelikli amaç operatörün uyguladığı kuvveti azaltmaktır. Bu kapsamda mevcut modele göre kol boyu $\left(X_{1}\right)$ uzatılarak uygulanan kuvveti en aza indirgemek ve mevcut modelde kullanılan teknolift mandalının ergonomisini arttırmak amacıyla omuz desteği ile avuç içine alarak kullanımı hedeflenmiştir.

Kol Oranı $=\frac{X_{1}}{X_{2}}$

Burada $X_{1}$ el kuvvetinin uygulandığı noktanın dönme eksenine uzaklığını ve $X_{2}$ ise telin bağlandığı noktanın dönme eksenine uzaklığını ifade etmektedir. Kol oranının büyük olması operatörün daha az kuvvet uygulayacağını ve aynı zamanda teknolift kolunun daha uzun olması gerektiğini ifade etmektedir.

Mevcut tasarımın kol oranı Denklem (2) kullanılarak yaklaşık 1.5 olarak hesaplanmıștır. Bundan dolayı alternatif tasarımdaki kol oranının 1.5'tan daha yüksek olması hedeflenmiştir.

Kol Oranı $=\frac{37,8}{24,6} \cong 1,5$

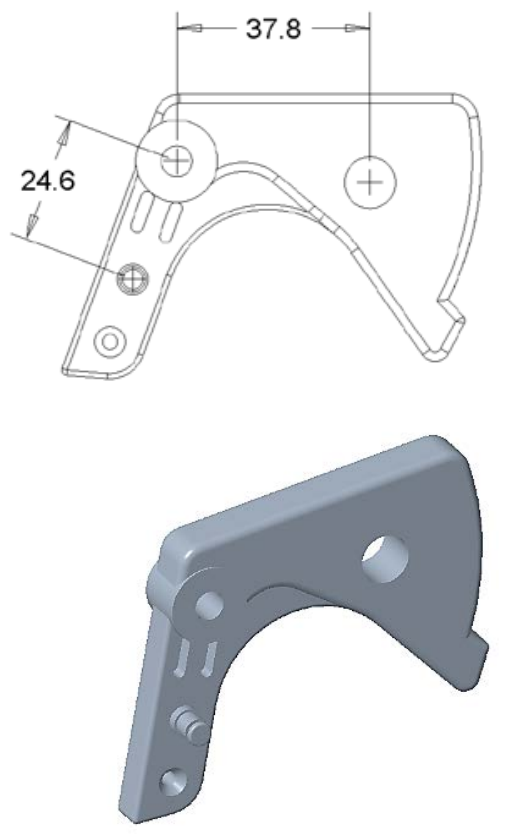

Şekil 7. Mevcut model
Alternatif tasarımın kol oranı ise Denklem (2) kullanılarak Şekil 8'de boyutları verilen alternatif tasarım için yaklaşı 5 olarak hesaplanmıștır. Bu sayede operatörün daha az kuvvet uygulaması sağlanacaktır .

Kol Oranı $=\frac{113,9}{22,7} \cong 5$

Alternatif tasarımı yapılan modelin teknolift levyesinin çalışma mesafesini tamamlayabilmesi için gerekli olan kuvvet, kol oranına oranlandığında operatörün uygulayacağı teorik yük (5) numaralı bağıntıda verilmektedir.

Operatörün uygulayacağı yük $=\frac{\begin{array}{c}\text { Teknolift levyesinin stroŭunu } \\ \text { tamamlayabilesi cinin gerekli kuvvet }\end{array}}{\text { Kol oranıı }}$

Şekil 5'te verilen mevcut teknolift mekanizmasına göre teknolift levyesinin stroğunu tamamlayabilmesi için kaldıraç denklemine göre (Denklem 1) hesaplanan yük 19 ile $30 \mathrm{~kg}$ arasında olmaktadır. Bununla birlikte operatörün gerekli stroğu sağlayabilmesi için (Denklem 5' göre) kol oranı 1.5 olan mevcut tasarıma uygulayacağı yük 12.6 $\mathrm{kg}$ ile $20 \mathrm{~kg}$ arası, kol oranı 5 olan alternatif modele uygulayacağı yük ise $3.8 \mathrm{~kg}$ ile $6 \mathrm{~kg}$ arasında hesaplanmıştır. Şekil 9' da yeni tasarlanan modelin mekanizma içinde kullanımı verilmektedir.
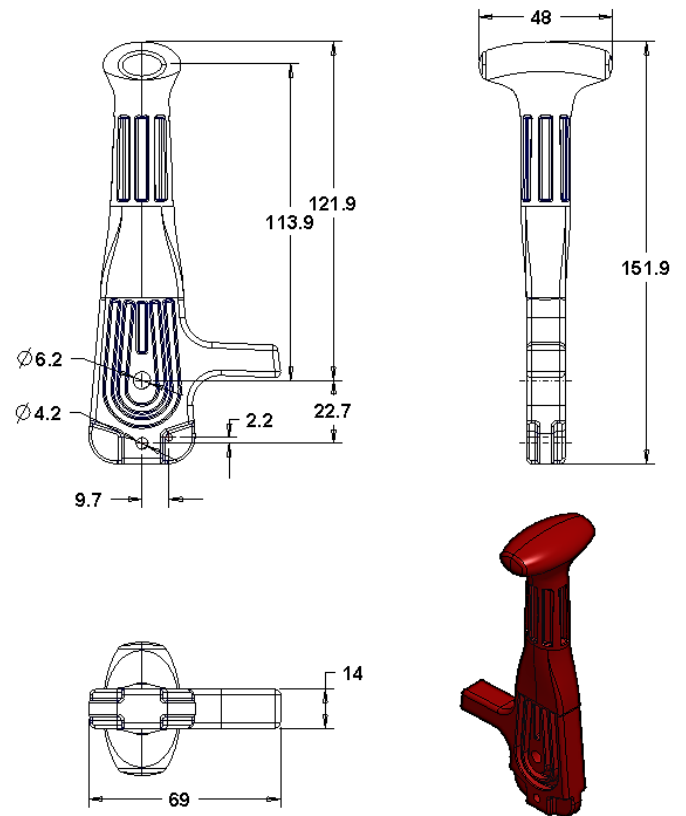

Şekil 8. Alternatif model 
Hızlı prototipleme yöntemi ile üretilen alternatif mekanizma, traktör üzerine monte edilerek yük hücresi ile ölçüm yapıldığında operatörün mekanizmayı çalıştırması için gereken yük değeri $3.5 \mathrm{~kg}$ olarak bulunmuştur (Şekil 10). Bu durum teorik hesaplama ile deneysel ölçüm sonuçlarının yakınlığını ortaya koymaktadır.

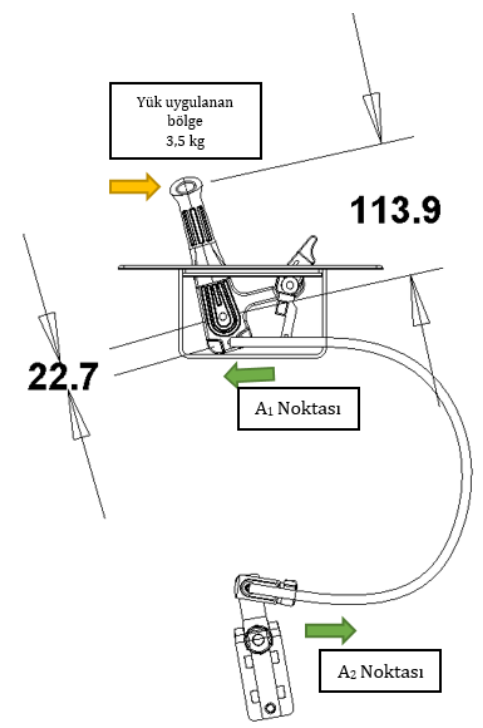

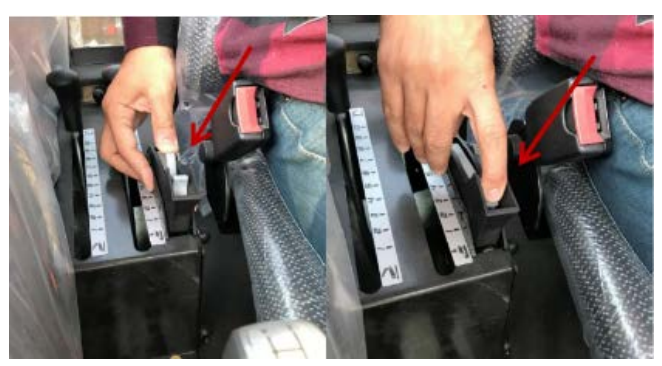

Şekil 11. Mevcut teknolift mandalın kullanım şekli

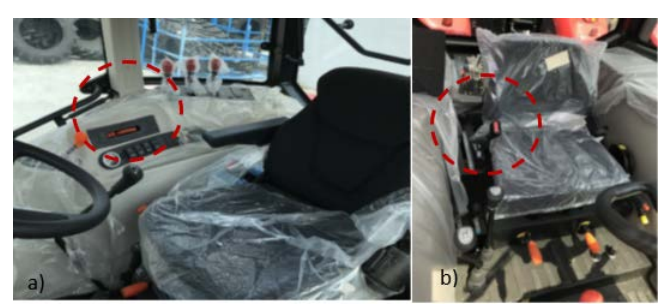

a) Sağ konsol üzerinde konumlu mevcut teknolift mandalı b) Koltuk yanında konumlandırılan teknolift mandalı

Şekil 12. Teknolift mandalların kabin/platform üzerindeki konumları

Yeni alternatif modelin kullanımı ve kabin içerisine monte edilmiş hali sırasıyla Şekil 13 ve Şekil 14'te verilmiştir. Buna göre Mary Marzke'nin [8] objeleri tutmanın farklı yöntemlerinin ergonomik açıdan sınıflandırması da göz önüne alındığında ve șekillerden görüldüğü üzere geliștirilen yeni model ile daha ergonomik tutma olanakları sağlanmaktadır.

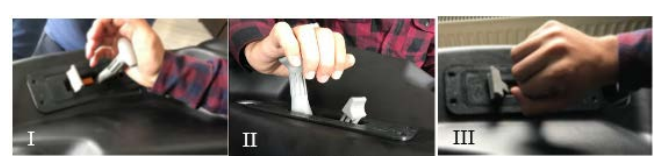

Şekil 13. Alternatif tasarım teknolift kolunun farklı kullanım şekilleri

\section{Konumları}

Traktörlerde kullanılan mevcut teknolift mandalları tasarımları gereği Şekil 11'de görüldüğü gibi başparmak ile bastırılması ve Şekil 12'de görüldüğü gibi farklı konumlarda kullanılmasından dolayı ergonomik değildir. 


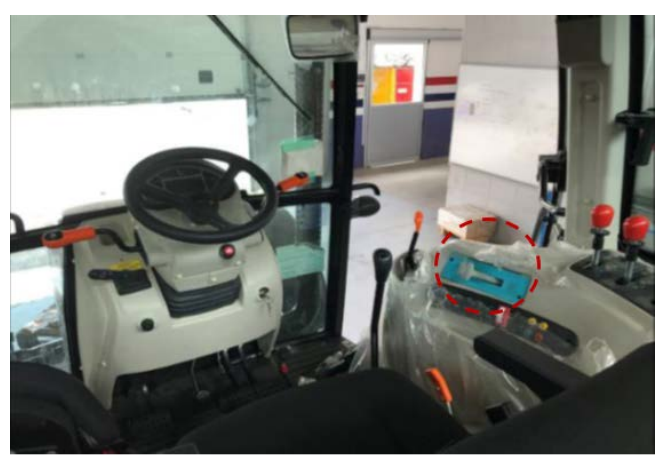

Şekil 14. Alternatif olarak tasarlanan ve üretilen teknolift kolunun konumu

\section{Sonuçlarin İrdelenmesi}

Operatörün mekanizmayı çalıştırabilmesi için gereken yükleme değeri, yük hücresi ile ölçülmüştür ve çlkan sonuçlar Tablo 1'de verilmiştir. Mekanik sistemde pim bağlantılarındaki çalışma boşlukları ve sürtünmelerden dolayı teknolift levyeyi hareket ettirmek için gereken kuvvet telli mekanizmaya göre daha yüksek çlkmaktadır. Telli mekanizmada ise teknolift levyeyi hareket ettirmek için itme-çekme teli kullanılmaktadır. $\mathrm{Bu}$ yüzden teknolift levyeyi çalıștırmak için mandala uygulanan yük daha düşük çıkmaktadır. Yeni tasarlanan teknolift kolları sayesinde gerekli olan yükler $8.2 \mathrm{~kg}-12.5 \mathrm{~kg}$ aralığından 3.5kg'a düşürülerek en az \% 58 en çok \% 72 azalmıştır. Bu sayede mevcut kolun kullanımına göre iş kaybında azalma sağlanmıştır.

Tablo 1. Teknoliftin çalıșması için gerekli olan yükler.

\begin{tabular}{ll}
\hline Model & Yük $(\mathrm{kg})$ \\
\hline Mevcut sistem (Mekanik) & 12.5 \\
Mevcut sistem (Telli) & 8.2 \\
Alternatif sistem & 3.5 \\
\hline
\end{tabular}

\section{Tartışma ve Sonuçlar}

$\mathrm{Bu}$ çalışma neticesinde çıkan sonuçlar aşağıda sıralanmıștır:

Geliştirilen alternatif kol tasarımı kol/omuz desteğiyle ittirildiği için uzun süreli kullanımlarda herhangi bir fiziksel sorun teşkil etmeyeceği düşünülmektedir.
Traktör üzerindeki kol sistemlerine gelen yükler, yük hücresi ile ölçülmüștür ve bu değerler mekanizma üzerindeki parçalara uygulanarak levyeyi çalıștırmak için gereken teorik yük değerleri bulunmuştur. $\mathrm{Bu}$ teorik olarak hesaplanan sonuçlar telli ve mekanik sistemler üzerinde $3.8 \mathrm{~kg}$ ile $6 \mathrm{~kg}$ arasında çıkmıștır. Telli sistem üzerinde monte edilen yeni tasarımın deneysel ölçüm sonucu ise $3.5 \mathrm{~kg}$ olarak ölçülmüştür. $\mathrm{Bu}$ durum teorik hesaplama ile deneysel ölçüm sonuçlarının yakınlığını ortaya koymakladır.

Geliştirilen alternatif tasarımının kol oranı mevcut tasarıma göre daha yüksek olduğundan dolayı operatörün sistemi çalıştırması için yaklaşık \%58-72 oranında daha az kuvvet harcamasını gerektirmektedir.

Yeni tasarımın kabin içerisinde farklı konumlarda oluşu, ergonomik yapısı ve kullanım kolaylı̆̆ gibi faktörlerden dolayı operatörün iş kaybının önüne geçilerek verimliliğin arttırılması amaçlanmaktadır.

\section{Teşekkür}

$\mathrm{Bu}$ çalıșmanın maddi açıdan desteklenmesine olanak sağlayan Sakarya Üniversitesi Bilimsel Araștırma Projeleri (BAP) Komisyon Başkanlı̆ı̆na (Proje No: 2017-50-01053) teșekkür ederiz.

\section{Kaynakça}

[1] Sabancı A., 1997, Tarım Traktörleri Ç.Ü. Ziraat Fakültesi Ders Kitapları Genel Yayın, No:46, Adana, Bölüm 6-7, s. 113-167.

[2] Olcay T., Kontrol mekanizması gövdesine tümleşik dıstan silindirli hidrolik kaldırıcı tasarımı ve deneysel olarak incelenmesi, Namık Kemal Üniversitesi, Fen Bilimleri Enstitüsü, Yüksek Lisans Tezi, 2014, Tekirdağ.

[3] www.mitaoleodinamica.com, (Erişim Tarihi: 13.08.2018).

[4] Lift H., 1992, Hydraulik in der Landtechnik, Grundlagen, Anwendungen, Fehlersuche, Würzburg, Germany.

[5] Baslo M., 2002. Ofis ergonomisi - sirt ve boyun ağrılarını önlemek için ofis ortamını düzenlemek, İstanbul Üniversitesi, Cerrahpaşa Tıp Fakültesi Sürekli Tıp Eğitimi Etkinlikleri, Baș, Boyun, Bel Ağrıları Sempozyum Dizisi 30, 155-165.

[6] Babalık F.C., 2005, Mühendisler için ergonomi işbilim, Nobel basımevi, Ankara.

[7] Choi, T.Y. and Like, J.K., 1992, Institutional conformity and technology implementation: A process model of ergonomics dissemination, Journal of Engineering and Technology Management cilt. 9, s. $155-195$.

[8] Mehta C.R., Tiwari P.S., Rokade S., Pandey M.M., Pharade S.C., Gite L.P., Yadav S.B., 2007, Leg strength 
DEÜ FMD 22(66), 691-699, 2020

of Indian operators in the operation of tractor pedals, International Journal of Industrial Ergonomics, cilt. 37, s. 283-289.

[9] Feyzi M., Navid H., Dianat I., 2019, Ergonomically based design of tractor control tools, International Journal of Industrial Ergonomics, cilt. 72, s. 298-307.

[10] Yisa, M.G., 2002, Ergonomics of tractors assembled in Nigeria, Biosystems engineering, cilt. 81, s. 169-177.

[11] Daeijavad S. and Maleki A., 2016, Proper farm tractor seat angles for the right posture using FEM, Computers and Electronics in Agriculture, cilt. 124, s.318-324.

[12] Mehta C.R. and Tewari V.K., 2015, Biomechanical model to predict loads on lumbar vertebra of a tractor operatör, International Journal of Industrial Ergonomics, cilt. 47, s.104-116.

[13] Li H., Zhao D., Ma X and Jin X., 2019, Predictive model of tractor driving posture considering front and rear view, Biosystems Engineering, cilt. 185, s. 64-75.

[14] Mehta C.R., Shyam M., Singh P., Verma R.N., 2000 Ride vibration on tractor-implement system, Applied Ergonomics, cilt. 31, s.323-328.

[15] Dewangan K.N. and Tewari K., 2009, Characteristics of hand-transmitted vibration of a hand tractor used in three operational modes, International Journal of Industrial Ergonomics, cilt. 39, s. 239-245.

[16] Lin J.H. and Xu X., 2019, Occupational cranking operations: The scapula perspective, Applied Ergonomics, cilt. 75, s. 129-133.

[17] Rajan V.N., Sivasubramanian K., Fernandez J.E., 1999, Accessibility and ergonomic analysis of assembly product and jig designs, International Journal of Industrial Ergonomics, cilt.23, s. 473-487.

[18] Muffett B., Wilson J.R. , Clarke T., Coplestone A., Lowe E., Robinson J and Smith S., 2014, Management of personal safety risk for lever operation in mechanical railway signal boxes, Applied Ergonomics, cilt. 45, s. 221-233.

[19] Akyeampong J., Udoka S., Caruso G., Bordegoni M., 2014, Evaluation of hydraulic excavator HumanMachine Interface concepts using NASA TLX, International Journal of Industrial Ergonomics, cilt. 44, s. 374-382.

[20] Nathanael D. and Marmaras N., 2018, From the seat to the system: Re-designing a tram drivers workstation combining technical and contextual aspects, Applied Ergonomics, cilt. 73, s.214-226.

[21] Kuta L., Stopa R., Szyjewicz D., Komarnicki P., 2019 Determination of comfortable position for tractor Driver's hands based on dynamic load, International Journal of Industrial Ergonomics, cilt. 74, s. 1-7.

[22] Sennett, R. 2009. Zanaatkâr Craftsman. (M. Pekdemir, Trans.). (1st. ed, syf. 198-200, 226-231). İstanbul: Ayrıntı yayınları. ( Orijinal baskı 2006).

[23] Sarabi İ.H.Z., Yașlilar İçin Tasarim: El Kullaniminda Fiziksel Güç Engeli Üzerine Ergonomik Bir Araștirma, İstanbul Teknik Üniversitesi, Fen Bilimleri Enstitüsü, Yüksek Lisans Tezi, 2013 , İstanbul.

[24] Brough, W. R., 1994, Ergonomics, Washington.

[25] Gregor H., Bojan D., 2014, Comparison of subjective comfort ratings between anatomically shaped and cylindrical handles, Applied Ergonomics, cilt 45, s. 943-954. 